\title{
Albania's Constitutional Court as a Guarantor of Fundamental Rights
}

\author{
Evalda Jera \\ Lgj: Naim Gjylbegu, Rr: Bujar Bishanaku, Pall 1016, Shkoder, Albania \\ Email: evaldajera@yahoo.com
}

Doi:10.5901/ajis.2015.v4n2p231

\begin{abstract}
The democratic changes that occurred in the early 90s marked a fundamental turn in the history of the Albanian State and its institutions. The democratic orientation of the state involved the commission of a deep institutional reform, which should open the way for democratic transformations to set up the rule of law and respect for The Human Rights. The Constitutional Court, as one of the most important institutions guaranteeing new constitutional order that was stationed in Albania. Since the beginning this institution was considered, by the Legislature, as the highest authority that guarantees respect for the Constitution and makes final interpretations of it. The Constitutional Court is recognized that it exercises control over judicial decisions and is limited in operation to protect the constitutional rights of every individual to a fair trial. The right to a fair trial is affirmed in Article 42 of the Constitution of the Republic of Albania and has the character of a right-constitutional guarantee. According to the Constitution Constitutional Court guarantees respect for the Constitution and makes its final interpretation, but the Constitutional Court also examines individual complaints of violation of their constitutional rights to a fair trial even after being exhausted all legal remedies to protect their.
\end{abstract}

Keywords: Law, Constitutional Court, democratic changes, human rights, fair trail

The democratic changes that occurred in the early 90s marked a fundamental turn in the history of the Albanian State and its institutions. The democratic orientation of the State involved the commission of a deep institutional reform, which should open the way for democratic transformations to set up the rule of law and the respect for The Human Rights. The basic principles that guided these democratic changes were originally announced by law no 7491, on April 04, 1991. For the major constitutional provisions, later on law no.7561 on April 04,1992, on amendments and additions to the Law No. 7491 dt.29.04 1991 for the major constitutional provisions. Within these changes, was created Constitutional Court, as one of the most important institutions guaranteeing new constitutional order that was stationed in Albania. Since the beginning this institution was considered by the Legislature, as the highest authority that guarantees the respect for the Constitution and makes final interpretations of it. Under this constitutional basis Constitutional Court was composed of nine members, five of whom were elected by the Assembly and four by the President of the Republic.

\section{President of the Constitutional Court}

President of the Constitutional Court shall be appointed from among the members of the Constitutional Court by the President for three years ...(Article 125 of the Constitution)

\section{Members of the Constitutional Court (Judges)}

The Constitutional Court consists of nine members, appointed for a term of 9 years, with no right to reappointment. Constitutional judges are appointed by the President with the consent of the Parliament. A third of the composition is renewed every three years. Judges must have higher legal education, have high qualification work experience not less than 15 years. Constitutional judges enjoy immunity. They can not be prosecuted without the consent of the Constitutional Court (Article 126 of the Constitution). Also they can not be removed, except in cases provided for by the Constitution (Article 128). Also constitutional function of a judge is incompatible with any other public or private activities (Article 130 of the Constitution).

The judge constitutional mandate ends when:

- punished with a final decision for commission of a crime;

- not without reason to work for more than 6 months;

- reaches the age of 70 years;

- resigns; 
- declared incompetent to act with a final decision

One of the main role of the Constitutional Courtshall is to guarantee the freedom and fundamental human rights. Albania's Constitutional Court plays a vital role in protecting fundamental freedoms and human rights by serving as a fourth level of appeal as well as being a last resort national appeal. The Constitutional Court guarantees respect for the Constitution and makes its final interpretation. The Constitutional Court is recognized that it exercises control over judicial decisions and is limited in operation to protect the constitutional rights of every individual to a fair trial.

For the first time in the Albanian legislation mentioned due to the process of law, precisely in law no. 7491, dated 04.29.1992, "On the main constitutional provisions" and more specifically in constitutional law No. 7692, dated 31.03.1993 "On the Rights and Fundamental Freedoms", realizing that the Constitutional Court may assess ways of interpreting and applying the law in principle belongs to the ordinary system only if between this process violated the constitutional rights of the individual to a fair trial. The individual can not address the common court with a lawsuit which has as its object the law objection due to violation of his legal rights. So it is unacceptable that any citizen could oppose a common law court claiming violation of his fundamental rights. If ordinary court allowed an appeal to challenge a law as unconstitutional, then the decision by the court should be the ergo omens and not inter parts as well as have the effect on these decisions. The right to a fair trial as the term is used in the Constitution means "fair trial" the equitable process in English and French, which means that we are dealing with, fair, and referring to the decision made as well as the procedural rules, and due to legal process refers to more procedural implementation sides. (Omari, 2008; p 277) "Constitutional standards such as the right of protection, equity in the trial, public hearing, presumption of innocence, key elements that the Constitutional Court has consolidated its jurisprudence for more complete understanding of the right to a fair trial law (Constitutional Court decision nr.8, 2003, p 37) " This is a guarantee for citizens against unjust actions of state power bodies, as well as an obligation of the organs of state power to not affect the rights and freedoms of citizens without ensuring observance of the relevant legal procedures. Due Process is a constitutional guarantee against any deprivation individuals that may be made of their basic rights by state individuals against any deprivation that may be made of their fundamental rights by the state, through its decision-making bodies. Being an integral feature of the rule of law of the Republic of Albania Constitution provides due process in its Articles 2 and precisely in Article 42 and 131. Article 42 refers not only to the freedom of property, but also to all rights recognized, not only by the Constitution, but also by other laws, with no constitutional character. So we can say that the right to a fair trial, Our Constitution does not limit the rights and civil liability but also extends to the whole of the rights enjoyed by citizens, even those rights that are not constitutional but instead other unconstitutional laws are recognized. This right can not be restricted even in cases of emergency. Characteristic of the right to a fair trial is the fact that at least at first glance it looks like the only right in the Constitution that provides status to protect the Constitutional Court. But this reality would be accurate only if we talk about this right in the procedural sense, not in the core (Omari, Anastas, 2008; pg157). It must be said that despite regular judicial process is an essential part of this right, not always a need for the existence of a trial for human rights find a direct guarantee in the Constitution and laws. For example if the individual exercises freedom of expression a right guaranteed in the Constitution making direct public opinions in the media it can not be subject to any judicial process. Due Process is not only guarantee against arbitrary actions that can perform state authorities over liberty, property and other constitutional rights but also procedures and fair trial rights. Article 42 of the Constitution provides for the right of the individual to a fair trial not only in litigation, but also in administrative disciplinary nature. Firstly required to liberty, property, constitutional or legal rights have been violated and secondly the infringement of rights be conducted without offering the person an appropriate judgment and legal right. The second paragraph of Article 42 of the Constitution begins by declaring that everyone has the right to a fair and public trial. From this it appears that the first element of a due process hearing is publicity, which meets two requirements on the one hand constitutes a significant procedural guarantees for the defendant and the other side responds interests of the community to a greater transparency of the judicial system (Tartari, 2008; pg 102). Constitutional jurisprudence has made interpretation of the letter $f$ of section 131 has restricted the access of the individual to the Constitutional Court only in terms of procedural legal process, which means that the individual is not legitimated to ask the Constitutional Court to protect his rights fundamental when it is directly affected by a law unconstitutional. Thus the Constitutional Court has recognized that it violated one of the essential elements of due process that has to do with the competent court when the court of first instance has not judging panel with an issue that had to do with the rejection of the administrative act with a value significant and objectively measurable (The decision of the Constitutional Court dated 12.12.2003, No. 35, of decisions 2003, pg 175). Given that freedom, property and other rights may be affected only after a due process hearing, entitled Constitutional Court stated that '... no administrative body does not have standing to carry out acts or unilateral actions that harm relations respective parties in a contract between them. (The decision of the Constitutional Court dated 17.11.1992, decisions 1992-1996, pg 
47). "Do we violation of the principle of impartiality in the case when the participation of the same judge, for trials initiated by the same person on different issues? Constitutional Court says no violation of the neutrality we violation which would come if you tried the same litigation. The Constitutional Court in its jurisprudence states that "judicial proceedings are open constitute an essential feature of the right to a fair trial, protecting litigants against the administration of justice in secret with no public oversight, fulfilling the basic principles of a democratic society. The Constitutional Court held that the right to a fair trial includes itself as one of its elements crucial impartiality of the court in the proceedings, which normally understood unless proved the opposite (The decision of the Constitutional Court dated 04.25.2003, No. 16, Decisions 2003, pg 77). The Constitutional Court has considered the lack of impartiality of the court by sj overcoming the limits of the issue, stating -by for those that are not required by the plaintiff. Also unilaterally accepting requests only one party and absence of the arguments submitted by the other (The decision of the Constitutional Court dated 02.07.2003, No. 20, Decisions 2003, pg108). The impartiality of judges affected by subjective attitudes held by the court in the course of the process by allowing the performance or non-performance of those essential procedural actions relating to the drafting of the request, notices or knowledge of the parties to the trial, which create reasonable suspicion to the defendant that the court will not appear impartial in resolving the issue (The decision of the Constitutional Court dated 22.12.2003, No. 37, Decisions 2003, pg 183). The reasoning of judicial decisions a very important element of due process. The Constitutional Court has found the elements of an irregular legal process even when between descriptive reasoning part of a judicial decision ordering his part are observed to mismatch, or when the same issues were given two decisions (The decision of the Constitutional Court, dt 29. 12. 1998, No. 76, Decisions 1997-1999, pg 224). A crucial aspect for a fair hearing is also the execution of judicial decisions. In 2000 the Albanian Constitutional Court had considered the request of a subject to the execution of the court decision final as a matter outside its jurisdiction, without first so the execution of final decisions related to Article 42 of the Constitution, nor with Article 6 of the European Convention on Human Rights concerning the right to a fair trial. Albanian Constitutional Court failed to correct its position by a decision in March 2006 which referring to Strasbourg decisions, among other things stated: "... the whole judicial process, often difficult and problematic, there would be no value in If it does not will be followed by a process that relates directly to the activity of the organs of execution, the execution of the decision or the realization of the right to fituar."'thus emphasized the obligation to enforce the judgment not only by agencies in order exclusive deal with their implementation but also to other entities for which the obligations stemming from the relevant decisions. It has considered the appeal of citizens to the Constitutional Court regarding the execution of judgments of the final, as closely related to Article 13 of the European Convention on Human Rights, namely the right to an effective remedy before national bodies also when the offense may have been committed by persons acting in an official capacity (Anastasi, 2009; pg163).

Concluding we can say that in relation to Human Rights, Constitutional Court serves as a fourth level of appeal being the last resort appeal nationally, before subjects can be addressed to the European Court of Human Rights Committee of the Human Rights or other international bodies recognized by the Republic of Albania. The right to a fair trial is affirmed in Article 42 of the Constitution of the Republic of Albania and has the character of a right-constitutional guarantee. According to the Constitution Constitutional Court guarantees respect for the Constitution and makes its final interpretation, but the Constitutional Court also examines individual complaints of violation of their constitutional rights to a fair trial even after being exhausted all legal remedies to protect their. The right to a fair trial consists of two parts which are affected if you violate this constitutional right. Primarily affected freedom property, and rights recognized in the Constitution and secondly, this encroachment has come without a fair trial. It relates specifically to the protection of the rights of individuals, as they may address the Constitutional Court only in relation to the violation of their rights to a fair trial.

\section{References}

Anastasi, A. (2009). Comparative Constitutional Law: "DAJTI 2000".

Omar, L. (2008). Rule of Law: Elena Gjika.

Omar, L., Anastasi, A. (2008). Constitutional Right.

Tartarian, A. (2008). Judicial and other writings.

Constitutional Court Decision no. 8, dated 03.25.2003.

The decisions of the Constitutional Court in 2003, Decision dated 02.07.2003, No. 20.

The decisions of the Constitutional Court in 2003, Decision dated 04.25.2003, No. 16.

The decisions of the Constitutional Court in 2003, dated 22.12.2003, No. 37.

The decision of the Constitutional Court, dated 12.12.2003, No. 35.

The decision of the Constitutional Court, No. 76, dated 25.04.2002

The decisions of the Constitutional Court 1997-1999, dt29 decision. 12. 1998, No. 76,

The decisions of the Constitutional Court 1992-1996, decision dated 11.17.1992 
